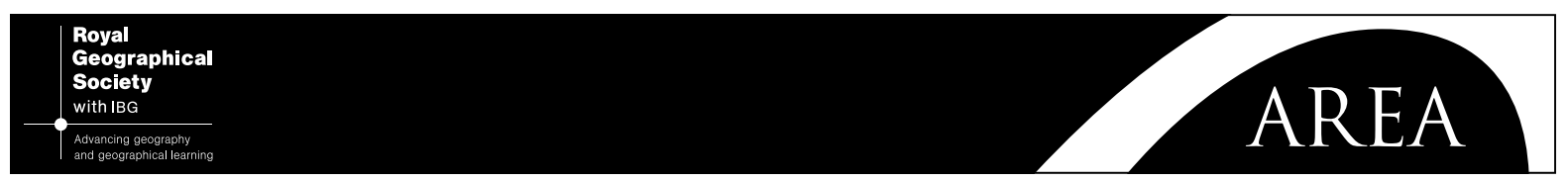

\title{
Practising workplace geographies: embodied labour as method in human geography
}

\author{
Chris McMorran \\ Department of Japanese Studies, National University of Singapore, Singapore 117570 \\ Email: jpscmm@nus.edu.sg
}

Revised manuscript received 6 March 2012

\begin{abstract}
Embodied experience, situated corporeal knowledge(s), and bodily mobility lie at the forefront of many research agendas within geography. However, the body has been largely ignored in workplace studies. That is, the context-specific, embodied daily practices of work remain overlooked within workplace geographies. In this paper, I reiterate a call made nearly two decades ago for more analyses of 'bodies at work' in geography, and I suggest a way of studying bodies at work that integrates the context-specific concerns of labour geographers with the theoretical interest on the body found elsewhere in geography: working participant observation. I claim working participant observation provides an opportunity to analyse how generic ideas about flexible labour are put into practice and creatively adapted by bodies in the workplace, especially in service industries. Through a description of working participant observation carried out in a handful of inns in Japan, I discuss how this method allows one to conduct research through the body and enables geographers to take seriously the spatiality and creativeness of embodied work practices.
\end{abstract}

Key words: workplace geographies, participant observation, qualitative research, body, tourism, Japan

\section{Introduction}

Each evening brings new challenges for the staff at Yamazakura, a family-run inn in the hot springs village of Kurokawa, located in southern Japan. This is truest for the six women who hold the position of nakai. As the 'face of the inn', they meet guests in the lobby, escort them to rooms, introduce the inn's facilities, serve dinner, lay out bedding and otherwise make guests feel at home, largely within the intimate space of the guestroom. They cater to a variety of guests, including couples of all ages, small groups of friends or colleagues, and families with children, who stay at inns like Yamazakura to celebrate a birthday or anniversary, escape the city or have a romantic getaway. As the guests and their expectations vary, so must the service provided by the nakai. Sometimes they must be entertaining, pouring drinks and enlivening the meal with witty conversation. At other times, they are expected to provide sage travel advice about the best sights to visit nearby. Occasionally they need to blend into the background, to deliver each course and remove empty dishes as invisibly as possible, so as to not disturb an icy lovers' quarrel.
The nakai lottery begins each day at 3 pm, when guests begin to check in. The nakai do not know precisely when guests will arrive or what they will be like. They only know if a group consists of, say, three females, or a couple, information requested when taking reservations so that the staff can prepare the appropriate slippers, robe and toiletries. As they wait for guests to check in, nakai do mundane tasks and speculate about the people with whom they will spend upwards of two hours.

Today, three women sit with me on the floor of the large hall, surrounding a pile of clean towels. We slowly fold them and place them in neat stacks of ten. Two other nakai shuttle cold dishes from the kitchen and place two servings of each item into serving trays. Another nakai arranges a large vase of flowers in the alcove. Everyone stretches out their tasks and conserves energy as they wait for the phone to ring. Finish quickly and time moves slowly, or one risks being asked to help with something less appealing. When a call finally comes from the front desk, Suzuki-san (58) answers. She calls out 'Pine!' and hangs up. Hearing the name of one of her two rooms, Komura-san (64) struggles to her feet, rubs some life into 
her legs, and glances at the evening's plan. 'Pine. A couple. I wonder if they are married?' She removes some lint with a roller and checks her makeup in the mirror. Smiling broadly, she slides open the door and steps into her slippers. It's showtime. I place another towel on the pile and wonder about the guests she will have tonight, as well as what version of herself she will be.

The nakai's backstage preparation and subsequent catering to varied tourists in the intimate space of the guestroom provides a concrete example of flexible labour, a core idea in geographical literature on the service industry, but one that is poorly defined. Maybe the problem is that too few geographers participate in flexible labour, leaving them to write about it in the abstract. Maybe more geographers need to become 'bodies at work'.

\section{Geographies of work}

Recently geographers have been avoiding work. At least as an explicit research topic, work has been largely absent from the geography agenda. Given that paid employment fills around half of the waking hours of most adults, this lack of scholarship constitutes a serious omission. ${ }^{1}$ Of course, work (and labour ${ }^{2}$ ) has not been completely forgotten. Titles like Spatial divisions of labor (Massey 1984), Gender, work, and space (Hanson and Pratt 1995), Workplace (Peck 1996), Labor geographies (Herod 2001) and Spaces of work (Castree et al. 2004) all indicate scholarship focused on the ever-shifting geographies of work. More recently, geographers have analysed the growing international division of labour (Wright 2006), the domestic and transnational flows of workers (Pratt 2004), the changing face of labour movements around the world (Silvey 2003), and the feminisation of work (McDowell 1997 2003).

All of this scholarship is characterised by a genuine desire to understand how people make a living amid shifting economic conditions, as well as a belief in the importance of place and space in determining labour geographies. Context matters, as Castree et al. explain in Spaces of work: 'What happens to workers, and what workers do in response, is ineluctably context specific' (2004, xvi, original emphasis). However, despite this interest in the spatial factors that impact workplaces, the embodied daily practices that constitute a job remain overlooked.

The body has been ignored in workplace studies precisely when interest in the body has grown among geographers in general, with embodied experience, situated corporeal knowledge(s) and bodily mobility at the forefront of many research agendas (Nast and Pile 1998; Crang 2005; Adey 2010; Dyck 2011). The neglect has worked both ways, with the burgeoning scholarship on the body mostly ignoring work and workplaces. This has occurred despite the fact that an increasing number of jobs now involve at least some form of 'interactive service work' (Leidner 1993), that which involves a face-to-face interaction between the customer and an employee whose embodied (gendered, aged, able-bodied, raced) performance is "part of the "product" that is "sold" to the customer' (McDowell 2003, 29). Recognising the importance of understanding this work nearly two decades ago, McDowell and Court called for more analyses of 'bodies at work' in geography $(1994,732)$. Few responded.

I reiterate this call and suggest a way of studying bodies at work that integrates the context-specific concerns of labour geographers with the theoretical interest on the body found elsewhere in geography. Along the way, I also hope to answer one challenge and refute one claim regarding qualitative methodology in geography. The challenge is from Mike Crang, who has noted the body is 'not yet something through which research is often done' (2005, 232, original emphasis; see also Crang 2003). The claim is from Alan Latham: 'We simply do not have the methodological resources and skills to undertake research that takes the sensuous, embodied, creativeness of social practice seriously' (2003, 1998).

I disagree. With respect to workplace geographies we have the resources. We simply are not using them. In this paper I argue that in order to study bodies at work, we need to conduct more working participant observation, or rolling up one's sleeves and working in the industry in question. Only then will we answer the methodological challenge of conducting research through the body. This will enable geographers to take seriously the creativeness of embodied work practices. In other words, in order to discover how generic theories about flexible labour and 'docile bodies' (Peck 2001, 6) are creatively put into practice by bodies at work, geographers must get to work.

I begin this paper by reviewing the use of working participant observation in the social sciences, pointing out its relative absence in geography. Then I describe my working participant observation in a handful of inns in Japan, which not only provided access to otherwise unreachable workers, but also helped answer questions about how notions of home were translated from management ideals to employees' bodies and about the possibilities and limitations of employee flexibility in the workplace. I conclude with remarks about the potential and limitations of working participant observation in geography.

\section{Studying work and the body}

Scholars anxious to unravel the complexities of work in contemporary society have often turned to working participant observation (Burawoy 1979; Diamond 1992; Ehrenreich 2008; Brannan et al. 2007; Hodson 2008). In 
Japan, working participant observation has been a mainstay of social scientific research for over 40 years (Cole 1971; Kondo 1990; Allison 1994; Whitelaw 2008). Strangely, few geographers have used this method. One rare exception is Philip Crang (1994), who studied how geographies of surveillance, display and location are enacted and resisted by staff in a restaurant in England. Another exception is Elizabeth Dunn (2004), who worked in a Polish factory to investigate its re-tooling by a capitalist firm, only to find that the process required the re-tooling of workers as 'flexible' capitalist bodies.

Alan Latham claims human geography suffers from 'methodological conservatism' (2003). This is often true in research on work. Despite a range of qualitative methods available to researchers (see Hay 2010; DeLyser 2010), geographers who write about labour rely heavily on interviews. Interviews may be useful for answering research questions about work histories and perceptions of work (e.g. Terkel 1974). However, they tend to remove employees from the workplace setting or interrupt the workday, thus de-coupling the subject of study (work and the body) from its context (the workplace) (see Elwood and Martin 2000 and Sin 2003 on interview location). Working participant observation, on the other hand, addresses the discipline's concerns with situated knowledge(s), the body and mobilities, and their intersections.

In order to address these concerns, geographers recently have incorporated interview aspects with the experience of doing activities. 'Go alongs' and 'talking whilst walking' (Anderson 2004) have provided spatial cues that stimulate discussion and reveal much about the relationship between location and subjectivity. Other scholarship in sub-disciplines like children's geographies has explored situated knowledge through in-situ interviews, which

allow the researcher, in the ethnographic tradition, to witness an array of embodied and emotional practices as they are experienced and performed by those involved ... [and they] allow these insights to be complemented by the researcher's own experiences of the same situations. (Anderson and Jones 2009, 300)

Anderson and Jones contend that this method 'affords elusive insights that make substantial advances in accessing the languages used by [participants] to articulate their worlds of everyday social practice' $(2009,300)$. Curiously, geographies of work have failed to keep pace, leaving others to blaze trails in understanding the relationship between mobilities, the body, and situated knowledge, and missing out on similar insights in the workplace. To remedy this, I call for geographers to conduct more working participant observation, or what one might call 'talking whilst working', since it allows observation of and participation in embodied labour and enables one to draw attention to gestures, speech patterns or other embodied aspects of labour as they occur, and to ask questions about these practices in situ.

Moreover, there is much that can be learned about work through working participant observation that goes beyond the verbal. Regarding the limits of talking about mobility, Peter Adey notes there is 'something in the act the doing of bodily mobility that surpasses our capacity to explain what that is through pages of verbal description' (2010, 142, original emphasis; see also Longhurst et al. 2008). The same holds with regard to work. Experiences like learning new tasks, negotiating one's position within complex hierarchies and social networks of employees and management, and sharing the emotional and physical stresses and joys of work all provide place-based insights into workplace attitudes, behaviours and meanings that would otherwise be difficult or impossible to learn. This is especially useful when studying practices that are commodified and displayed in the service industry, as is the case in many jobs in the tourist economy like those discussed below. Given the continued growth of tourism worldwide and service sector employment in general, the importance of the body as a conduit of cultural representation deserves increased attention. Working participant observation provides a valuable point of entry to these issues.

\section{Accessing workplaces}

For 12 months, I researched labour in the Japanese tourist industry by working in a handful of traditional inns (ryokan). ${ }^{3}$ I was curious about the transfer of knowledge from inn owners to employees and the ways that employees learn to embody a sense of place that is scripted as 'traditional' and 'Japanese' for mostly domestic Japanese guests. Inn owners aim to create a traditional Japanese sense of home in both their inn's built form and the style of service. A vital component of this 'tradition' is the embodied labour of the female nakai. As inn owners explained in interviews, the nakai portrays a female caregiver who makes guests feel welcome in this nostalgic 'home away from home'. This desire for nakai to create a home-like setting created an opportunity for me to witness and experience how service workers learn, interpret and alter management ideals through their embodied labour. This experience highlighted the everyday flexibility required in the service industry to manage customer expectations while also, when possible, to reclaim autonomy for workers who might otherwise find themselves immobilised by their lack of alternative employment options.

My research began with the knowledge, gained in a pilot study, that both inns and their nakai are difficult to access. I received a warm reception in many lobbies, but 
moving past this space was difficult. In a pilot study, I shadowed employees (Jirón 2011). However, their constant movement, cleaning rooms or delivering food in the inn's narrow spaces, left them tripping over me. Plus, despite feverish note-taking, employees saw me as someone who was not working. Eguchi-san ${ }^{4}$ (67), a future co-worker, later recalled that experience with amusement. 'I wondered, "Who is this strange foreigner, and why is he following me asking these questions?" ' Until I was a co-worker, I was a body out of place, neither tourist nor worker.

Compounding matters is the inn's long workday, which requires a very flexible staff to match tourists' bodily patterns. Guests arrive in mid-afternoon, eat a large meal between 6 and 9 pm, sleep, wake, eat breakfast from 8 to $9 \mathrm{am}$, and check out by $10 \mathrm{am}$. Employees must work around guests. Workers arrive at 7 or 7.30 am to prepare breakfast service, remain in the inn after check out to clean rooms, eat lunch, then leave for a short break. They return around $3 \mathrm{pm}$ to help guests check in, serve dinner and help clean the kitchen and other areas following dinner, finally leaving around 9 or 9.30 pm. Working participant observation allowed me to encounter workers physically hidden backstage in the inn's kitchens and pantries or too busy to meet outside the workplace.

\section{Flexibility in the service sector}

During my year, I welcomed guests, parked cars, carried luggage and trays of food, washed dishes, scrubbed baths, vacuumed and dusted guestrooms, and did whatever else was needed to create and embody a nostalgic sense of home for guests. At my primary workplace, a crew of 20 (15 women, 5 men) trained me in these tasks, while inadvertently demonstrating how to move through space, how to deal with guests, co-workers and management, and most importantly, how to translate the owner's nostalgic, gendered conception of home and hospitality into an affective and material product stemming, as inn owners desired, 'from the heart'. I found myself shortening and quieting my steps while walking in hallways and guestrooms, working with quick, polite humility in the presence of guests, and conjuring a convincing smile when necessary (Hochschild 1983). I also learned how to deflect requests by co-workers who took advantage of my position as newest staff member and non-Japanese, and eventually, how to bargain in the complicated marketplace of favours, expectations and refusals that is common to all workplaces, but that must be more delicately negotiated in the presence of guests. In all of these ways, I internalised the flexibility necessary not only to move bodily through the inn's narrow hallways and under its short doorways, but also to constantly recognise the needs of guests and co-workers and adjust myself to suit the situation.
Service sector employment is often notable for its use of flexible labour. Flexibility may refer to irregular work hours, lack of permanent employment or seasonality of work. Inns demand a certain type of flexible labour, namely individuals willing to work long, irregular hours (two shifts that add up to 9-10 hours a day, 6-7 days per week), usually on short contracts (3-6 months) or without contract. Employees must be mobile enough to move to distant locations that often lack a sufficient private housing market. In Kurokawa, most live in company dormitories, typically in a private or shared room with a tiny kitchen (or no kitchen) and a shared toilet. Because these dormitories are located near the inns, employees are always on call, expected to report to work at a moment's notice, even on their day off. They are also vulnerable to sudden visits by curious employers. While inn employees object to these privacy restraints, they often have no choice but to succumb to the whims of their employers, further exhibiting their flexibility.

However, flexibility is not limited to working hours, lack of permanent employment status and ability to be called at all hours of the day. Flexibility is required throughout the workday in workers' embodiment of the owner's version of home. It is important to note that inn owners give nakai relative autonomy to creatively produce a hospitable space without constant surveillance by management (cf. Crang 1994). Therefore, certain inn spaces, specifically guestrooms, become hybrid commercial/domestic spaces that workers consider the equal responsibility of both their bosses and themselves. For this reason, nakai have flexibility in how they embody the home away from home. They must be able to think on their feet, performing variations on their role depending on the guests. A pair of adventurous young female travellers may need the advice of an older sister to help them plan the next day's excursion to local hot springs or cafes. A group of older men may require a nakai to join their playful banter peppered with thinly veiled sexual innuendo. A couple with a small child may require a grandmotherly figure willing to admire the child and inquire about his age, hobbies, likes and dislikes.

These are critical shifts in role that are never mentioned in conversations with nakai outside the context of the workplace. This is because such flexibility, while understood as necessary, is considered so ordinary. Working participant observation enables one to witness examples of such everyday flexibility and comment on it immediately. In all cases, the nakai must cater to guests' needs while always reflecting positively on the inn owners. However, each nakai also takes the face-to-face interaction personally, as it is she who is on stage, humiliated by her errors or genuinely proud of compliments received. Through working participant observation, I witnessed the creativity co-workers utilised in working with guests, 
adjusting their personalities or postures when necessary, despite their insistence on their tasks being mundane.

\section{Bodies in space}

Over time I came to see the workplace marked by an extreme level of flexibility unacknowledged by workers. However, I also learned a critical lesson about the rigidity of some workplace geographies when one day I attempted to reclaim the inn as a space of research. Five months into the research, I began to work fewer days in order to meet employees and owners of other inns. One day, I arranged a lunch meeting with an employee of another inn on my day off. However, I rode in the employee shuttle of my regular inn in the morning and wrote in a spare guestroom before my meeting. Feeling tired at 9.45, I decided to join my co-workers at the morning break. As I slid open the door to the dining room, I overheard complaints about the current staff shortage and the fact that the inn owners were not actively recruiting. 'Good morning', I said, stepping out of my slippers and into the room and gently sliding the door closed behind me. Several women replied unenthusiastically, without the vibrancy used in front of guests. It was an energy conservation trick that I understood. Four women sat at the low table, one pouring tea while another handed out sweets received as a tip. Three other staff lay on the floor resting their eyes. The morning rush had ended, and everyone needed this 15-minute break to recharge before the flurry of cleaning the empty rooms before lunch.

I sat in my usual spot at the far end of the table and received a cup of tea from Tanaka-san (65). 'How's the studying?' she inquired. We had ridden together in the morning van.

'It's fine.' I smiled.

Then Komura-san looked up from the day's schedule and breathed a sigh of relief. 'Ahh, Kurisu, I'm glad you're here. You can clean the second floor with me.' Then her smile vanished. 'Where's your uniform?'

'Actually ...'. Guilt slowed my reply, 'I'm not here to work today. I'm studying.'

'What?!' she snapped. 'Why are you here if you're not working? If you're not working, I don't want to see you. You shouldn't be here. That's rude!' She rose, left the room, and didn't return for the rest of the break.

I was speechless. Komura-san frequently requested me to work with her. We worked efficiently and enjoyed each other's company. We had talked about her life following her husband's premature death, leaving her with two young children. She had shared her work history and her strong opinions about the management and other staff. Her anger stemmed from my presence in the inn while not working. Especially given the recent lack of sufficient bodies in the workplace, I was inadvertently parading my unavailable labour. Working participant observation had given me legitimacy in the inn's spaces of work, but for Komura-san, my legitimacy was contingent on my labour. My desire for the flexibility to be both researcher and worker transgressed an unwritten rule that one could only be a guest or a worker in tourist space. I was neither.

\section{Conclusions and caveats}

Given that work comprises a major part of most adult lives, it is imperative that geographers better understand not only where people work and what they say about their jobs, but also the unspoken aspects of work and workplaces that are difficult to address in interviews, surveys and other methods that are removed from the workplace context and its practices. If geographers want to better understand how place impacts labour geographies, they need to experience the everyday practices of labour in place. With increased importance of the body, both in service industries and in the discipline, working participant observation provides a way to take the body seriously as both an object of study and a tool through which research is conducted.

Working participant observation provides insights into the unwritten rules and complex interactions among employees, management and customers often missed by other research methods. It addresses concerns of researcher positionality by showing the researcher's willingness not only to 'get one's hands dirty', but also to negotiate work schedules and get 'stuck' working overtime. This inevitably builds trust with potential respondents that would otherwise be difficult. More importantly, working participant observation provides insight into the ways that physical workplaces create opportunities for creative, often genuine, encounters between employees and customers that are often trivialised in the literature as performances. Working participant observation enables recognition of the workplace as an ever-shifting space of surveillance, creativity and potential. It can be both mundane and extraordinary, and only by experiencing the rhythms of the workplace can a person understand the narrow yet significant distance between these two extremes.

That said, working participant observation also has its limitations. Some workplaces, like airline cockpits or Somali pirate ships, will never be accessible to this method because of concerns with security, training, ethics and more. On a personal level, my choice of working participant observation may have meant access to the inn, but it meant sacrificing certain freedoms enjoyed by others in the field. My schedule was fixed. I could not meet people at the spur of the moment, explore surrounding inns or chat too long with guests or co-workers. We were bodies in motion required to stay in motion. 
However, complete flexibility of time and physical movement would not have granted me access to backstage areas of inns, nor would it have attuned me to the limitations of time and space experienced by the people I wanted to study.

Sceptics may argue that the kind of long-term study of a workplace espoused here is increasingly difficult or even impractical given sped-up publication expectations and limited time for fieldwork. These are concerns for all who believe that both knowledge and rapport must be built over time and with great effort. I implore geographers to resist throwing ethnography and other longterm qualitative research methods by the wayside in order to satisfy requirements that encourage sacrificing quality for quantity. If geographers truly want to understand the complex geographies of work, they will need to devote the time and energy required to observe and experience work.

\section{Acknowledgements}

This research was supported by the National Science Foundation (DDRI Award \#0602711) and the Japan Foundation. Special thanks to my numerous coworkers in and around Kurokawa Onsen who inspired this work, as well as Jamie Gillen and Gavin Whitelaw for helpful comments on the paper.

\section{Notes}

1 Consider also the lack of a title on work or labour in Routledge's 'Key ideas in geography' series.

2 I equate 'labour' with 'work' as two ways of talking about paid employment (Arendt 1958). For brevity's sake, I do not address the complexities of unpaid labour/work and social reproduction, especially in the home (see Mitchell et al. 2004).

3 My research was overt, and I received verbal or written permission from all participants (see Lugosi 2006 on covert vs overt methods). In most inns I volunteered my labour. However, one inn owner insisted on paying the standard daily wage. When I tried to refuse, she pleaded with me to accept the money, explaining that otherwise she could not ask me to do the unappealing tasks required of everyone. This was an awkward but unavoidable situation for both of us created by the research method.

4 All names are pseudonyms. I have added the honorific suffix 'san' to all surnames, as is customary among most workers.

\section{References}

Adey P 2010 Mobility Routledge, London

Allison A 1994 Nightwork: sexuality, pleasure, and corporate masculinity in a Tokyo hostess club University of Chicago Press, Chicago IL

Anderson J 2004 Talking whilst walking: a geographical archaeology of knowledge Area 36 254-61
Anderson J and Jones K 2009 The difference that place makes to methodology: uncovering the 'lived space' of young people's spatial practices Children's Geographies 7 291-303

Arendt H 1958 The human condition University of Chicago Press, Chicago IL

Brannan M, Pearson G and Worthington F 2007 Ethnographies of work and the work of ethnography Ethnography 8 395-402

Burawoy M 1979 Manufacturing consent: changes in the labor process under monopoly capitalism University of Chicago Press, Chicago IL

Castree N, Coe N M, Ward K and Samers M 2004 Spaces of work: global capitalism and geographies of labour Sage, London

Cole R E 1971 Japanese blue collar; the changing tradition University of California Press, Berkeley CA

Crang M 2003 Qualitative methods: touchy, feely, look-see? Progress in Human Geography 27 494-504

Crang M 2005 Qualitative methods: there is nothing outside the text? Progress in Human Geography 29 225-33

Crang P 1994 It's showtime: on the workplace geographies of display in a restaurant in southeast England Environment and Planning D: Society and Space 12 675-704

Delyser D 2010 The SAGE handbook of qualitative geography Sage, London

Diamond T 1992 Making gray gold: narratives of nursing home care University of Chicago Press, Chicago IL

Dunn E C 2004 Privatizing Poland: baby food, big business, and the remaking of labor Cornell University Press, Ithaca NY

Dyck I 2011 Embodied Life in Del Casino Jr V J et al. eds A companion to social geography Blackwell, Malden MA 346-61

Ehrenreich B 2008 Nickel and dimed: on (not) getting by in America Holt Paperbacks, New York

Elwood S A and Martin D G 2000 'Placing' interviews: location and scales of power in qualitative research Professional Geographer 52 649-57

Hanson S and Pratt G 1995 Gender, work, and space Routledge, London

Hay I 2010 Qualitative research methods in human geography Oxford University Press, Oxford

Herod A 2001 Labor geographies: workers and the landscapes of capitalism Guilford Press, New York

Hochschild A R 1983 The managed heart: commercialization of human feeling University of California Press, Berkeley CA

Hodson R 2008 Workplace ethnography project home page (http://sociology.osu.edu/rdh/Workplace-Ethnography-Project. html) Accessed 26 September 2011

Jirón P 2011 On becoming 'la sombra/the shadow' in Büscher M, Urry J and Witchger K eds Mobile methods Routledge, Abingdon 36-53

Kondo D K 1990 Crafting selves: power, gender, and discourses of identity in a Japanese workplace University of Chicago Press, Chicago IL

Latham A 2003 Research, performance, and doing human geography: some reflections on the diary-photograph, diaryinterview method Environment and Planning A 35 19932017

Leidner R 1993 Fast food, fast talk: service work and the routinization of everyday life University of California Press, Berkeley CA 
Longhurst R, Ho E and Johnston L 2008 Using 'the body' as an 'instrument of research': kimch'i and pavlova Area 40 208-17

Lugosi P 2006 Between overt and covert research: concealment and disclosure in an ethnographic study of commercial hospitality Qualitative Inquiry 12 541-61

Massey D B 1984 Spatial divisions of labor: social structures and the geography of production Methuen, New York

McDowell L 1997 Capital culture: gender at work in the city Blackwell, Oxford

McDowell L 2003 Redundant masculinities? Employment change and white working class youth Blackwell, Malden MA

McDowell L and Court G 1994 Performing work: bodily representations in merchant banks Environment and Planning D: Society and Space 12 727-50

Mitchell K, Marston S A and Katz C eds 2004 Life's work: geographies of social reproduction Blackwell, Malden MA

Nast H J and Pile S 1998 Places through the body Routledge, London
Peck J 1996 Work-place: the social regulation of labor markets Guilford Press, New York

Peck J 2001 Workfare states Guilford Press, New York

Pratt G 2004 Working feminism Temple University Press, Philadelphia PA

Silvey R 2003 Spaces of protest: gendered migration, social networks, and labor activism in West Java, Indonesia Political Geography 22 129-55

Sin C H 2003 Interviewing in 'place': the socio-spatial construction of interview data Area 35 305-12

Terkel S 1974 Working; people talk about what they do all day and how they feel about what they do Pantheon Books, New York

Whitelaw G H 2008 Learning from small change: clerkship and the labors of convenience Anthropology of Work Review XXIX 62-9

Wright M W 2006 Disposable women and other myths of global capitalism Routledge, New York 